\title{
ポリマーブレンドの理論 $(\mathrm{I})$
}

\section{——混合物の半微視的不均一性を考慮した 2 成分ポリマー 混合系の混合状態に対する力学的表現}

\section{1. 緒毫}

2 成分ポリマー混合系の力学的性質はその混合状態に 大きく依存する11。二つのポリマーが完全相溶の場合は いわゆる分子状混合を呈し，混合物は二つのポリマーの モノマーを重合組成とするランダム共重合体のような挙

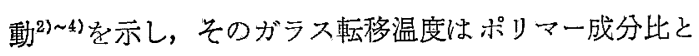
とるに系統的に変化し，ただ一つ存在する。このような 完全相溶の例はある範囲内の混合比でのポリ塩化ビニ ル/ブタジェソーアクリロニトリル共重合ゴムの混合系に

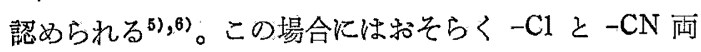
極性基間に強い相互作用性を生じ，一種の相互溶解現像 (solvation) が起こっているものと思われる。

ポリマー間に上述のよ5な完全相溶を有する系はきわ めてまれであって,一般には相溶性がきわめてそしいか, 非相溶の系が大半である。これらの混合状態は溶解とい らょりは一種の機械的混合であって，事実混合物におい ては両成分ポリマーのガラス転移温度は多少の温度のず れはあって子両成分に対応して二つ出現する7,8)。この ことから混合物は少なくとも個々の物理的性質を十分に 反映するような比較的大きい単独のポリマー相が混合し た半微視的に不均一な系と考えられ，混合の状態が混合 物の力学的性質を大きく左右するものと考えてよい。

相溶性ポリマー混合系が混合によって全く別種の単な る一独立成分相のごとき挙動を示し, 工業的, 技術的に あまり興味がないのに比較して，貧相溶性ないし非相溶 性ポリマー混合物が混合状態のいかんによって各成分ポ リマーの性質を残存してきわめて大幅に変化するため, 技術的にも興味のもたれるゆえんである。

一方，後者の混合系の混合状態を定量的に表現する方 法はまだ確立されて未らず，混合系を取り报う場合にな ず解決されねばならない問題の一つである。ここでは以 下に述べるような力学的挙動を記述する比較的一般的な

\footnotetext{
$*$ 京都大学工学部助教授・工博

** 東洋紡績株式会社㢣田瀻維技術研究所
}

\section{河合弘迪*・小川靖雄**}

現象理論に基いて混合系の混合状態を規定するパラメー タの誘導を試み，二三の実験結果の解析を紹介する。

\section{2. 単純な力学模型による機械的混合の表現}

貧ないし非相溶の 2 成分ポリマーが混合された場合， その界面での接触面積をなるべく最小に保つため, 一相 は平均的にある半径の球状に，他相はそれを包囲する傾 向があろ5。この状態を球の平均半径と両相の体積分率 を考慮した一体模型として，第 1 図 (a) に示されるよ5 に近似的に単位立方体叫にある大きさの球を浮べること によって表現できるでからう。このような分散状態は球 相の体積分率加増加して, 六方最密充てん（球相の分率 約 70\%) までつづき，これを境に相組成の逆転を生ず る。

ここでいずれの成分が球相として出発するかは両成分 間の特に界面の物理化学的性質によって定まるものと考 えられ，これが後述するよ5に混合系の力学的性質を最 む大きく支配する。したがって 2 成分機械的混合系を問 題にする限り，この組成の相分配に関する本質的原因を 探究することが最も重要な課題であろう。

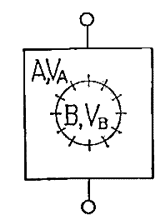

(a) $B$ in A型機械的混合

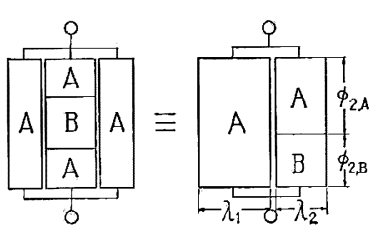

(b) 亚列模型

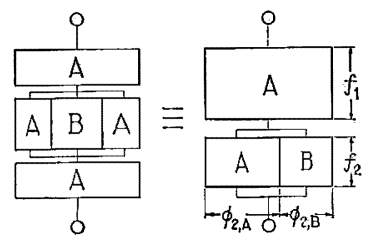

(c) 直列模 型

第 1 図 単純な A 海, B 島型機械的混合飞 対応する 2 種の力学模型 
さて，第1図 (a) の一体模型で A，B 2 相界面での 接着は比較的完全で宓って, 变形火際し脱接着は起こら ないと仮定する。この一体模型の引張変形を力学的に第

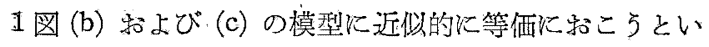
5ので岕る。第 1 図 (b) の模型は第1 図 (a) の一体模型 “タテ割り柱状” 飞分割し, 各柱状要素の部分応力 の全応力に対する寄与に加成性を仮定する，いわ流力 炕関する並列模型でせり，第1図 (c) は “ヨコ割り層 状” に分割し, 各層状要素の部分ひずみの全ひずみに対 する寄与に加成性を仮定する，いわばひずみに関する直 列模型である。

ここで注意すべき問題は，材質的飞相違する A, B 2

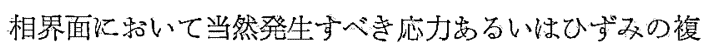
雜な分布をきわめて単純化していることである。すなる ち (b), (c) いずれの力学模型沈いて子要素内の異相間 の接着は完全で㚣るが，各琶素間にはなんらの相互干渉 はないとするのである。たとえば(b)の“タテ割り”模 型では各要素間の特に異相界面に和けるひずみの大きさ が相違する矛盾を無視したものであり，(c)の“ヨコ割 り”模型では各層内の伸長ひずみは均一であるが, 要素 間の特に異相界面に掠いて事際には収縮により生ずるひ ずみの大きさが相違する矛盾を無視している。

近似の程度からい党ば，(b) の模型で B 相の存在の 影響を少なく，(c) の模型では多く見積っていると考克 られるが，いずれにしてもこれらの界面に郝ける応力业 るいはひずみ分布を極度に単純化したことによる誤差 性, 次の簡単な試算に上って子示されるように, 全系の 力学的性質が組成の相分配性汇よって大きく支配される ことに比較すれば問題とならない。

第 1 図 (b), (c) 飞示された力学模型の引張変形㡜す る緩和弾性率 $E(t, T)$ は, 各相の引張緩和弾性率を艺れ でれ $E_{A}(t, T), E_{B}(t, T)$ とすれば次式で与竞られる。こ こで $t:$ 時間, $T:$ 温度で嵓る。

$$
\left.\begin{array}{l}
\underline{E}(t, T)=\lambda_{1} E_{A}(t, T)+\lambda_{2}\left\{\frac{\varphi_{2, A}}{E_{A}(t, T)}+\frac{\varphi_{2, B}}{E_{B}(t, T)}\right\}^{-1} \\
\lambda_{1}+\lambda_{2}=1 \\
\varphi_{2, A}+\varphi_{2, B}=1 \\
\lambda_{2} \varphi_{2, B}=V_{B}, \quad \lambda_{1}+\lambda_{2} \varphi_{2, A}=V_{A}
\end{array}\right\}(1)
$$

ここで $\lambda_{1}, \lambda_{2}$ は並列 2 要素の容積分率, $\varphi_{2, A}, \varphi_{2, B}$ は $\lambda_{2}$ 要素中の $\mathrm{A}$ 牰よび $\mathrm{B}$ 成分の分率, $V_{A}, V_{B}$ は全体 上しての A 特よび B 成分の分率である。

$$
\left.\begin{array}{l}
\underline{E}(t, T)=\left\{\frac{f_{1}}{E_{A}(t, T)}+\frac{f_{2}}{\varphi_{2, A} E_{A}(t, T)+\varphi_{2, B} E_{B}(t, T)}\right\}^{-1} \\
f_{1}+f_{2}=1 \\
\varphi_{2, A}+\varphi_{2, B}=1 \\
f_{2} \varphi_{2, B}=V_{B}, \quad f_{1}+f_{2} \varphi_{2, A}=V_{A}
\end{array}\right\}
$$

ここで $f_{1}, f_{2}$ は直列 2 要素の容積分率, $\varphi_{2, A}, \varphi_{2, B}$ は $f_{2}$ 要素中の $\mathrm{A}$ 敊上び $\mathrm{B}$ 成分の分率, $V_{A}, V_{B}$ 㹥全体 としての A 执よ゙ B 成分の分率である。

いる，単位長の立方体中に浮ぶ球を同体積の立方体に 近似し, $V_{B}$ が $0 \sim 1$ の間に変化する際に, 混合試料の 時間 $t_{0}$, 温度 $T_{0}$ 飞和讨名緩和弾性率 $E\left(t_{0}, T_{0}\right)$ の変化 を $E_{A}\left(t_{0}, T_{0}\right)=1 \times 10^{7}, E_{B}\left(t_{0}, T_{0}\right)=1 \times 10^{10} \mathrm{dyne} / \mathrm{cm}^{2}$ と して，第 (1) 䊉よび (2) 式を用いて試算を行ならと第 2 図のようになる。

図より明らかなよらに，第 (1) 式によって与兄られる 並列模型と第 (2) 式に上って与兄られる直列模型の挙動 は若干の相違は山っても, 著しい類似性を示し, 混合物 の挙動が要するに海となる相の力学的性質に支配される ことがわかる。

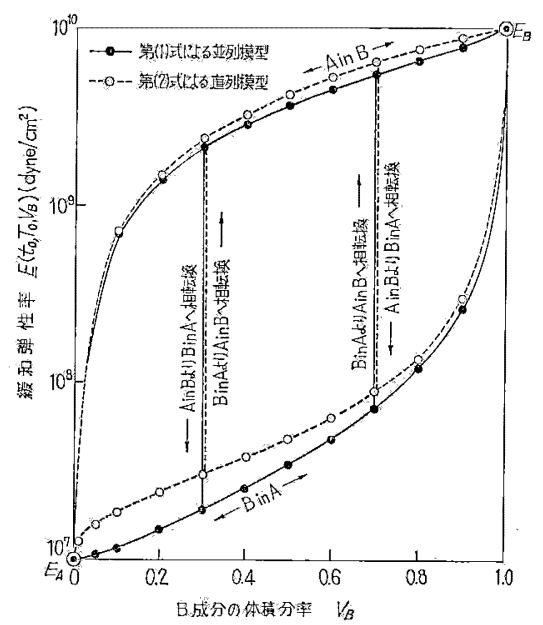

第 2 図 単純な機械的混合系の緩和弾性率 の混合分率依存性

すなわら柔らかい A 相中にかたい B 相が浮ぶ瑒合は， B 相の分率が 0.7 程度になっても $E$ は $1 \times 10^{8} \mathrm{dyne} / \mathrm{cm}^{2}$ を越すことなく, 分率が 0.7 を越し $\mathrm{B}$ 相の島側から見 て六方最密充てんとなり, 海一島の相の逆転が生じて初 めて $E$ は飛躍的に上昇し $1 \times 10^{10} \mathrm{dyne} / \mathrm{cm}^{2}$ のオーダに 達する。委た逆にかたいB 相中に柔らかい A 相が浮ぶ 埸合汇は $\mathrm{A}$ 相の分率が 0.7 飞達しても $\underline{E}$ は $10^{9} \mathrm{dyne} /$ $\mathrm{cm}^{2}$ のオーダを保ち，A 相の分率がそれ以上炕なって 初めて $\underline{E}$ 急激低下し，107ーダになる。したが ってここに注目すべき問題は，たとえば $V_{B}$ が 0 から 出発して, 0 0.3 の範囲内和㚈る $\mathrm{B}$ in $\mathrm{A}$ の性格に 2 と和りあるとである。一り蝶定に B in A とし て B の分率の增大ととるにこの混合様式を保つるのと, A 相の分率過剩のため，やむなく B in A の様式を保 っているるのの 2 種である。後者は $V_{B}=0.3$ を境界に 直ち炕り安定な $\mathrm{A}$ in $\mathrm{B}$ 一相転換を行ない, 著しくか たい混合系になる。同様のことが $V_{A}$ の $0 \sim 0.3$ の範囲 の $\mathrm{A}$ in $\mathrm{B}$ の性格以ついてもいえるであるう。これらの 事情は比較的, 少量の混合一成分でよりか店い，山るいは 
より柔らかい混合物を得ようとする技術的な目的には十 分に利用されるべきであるが，分率 0.3 あるいは 0.7 の 相転換を生ずる範囲は不安定な状態であり，巨視的に均 質な混合系の得がたいことも注意すべきであろう。

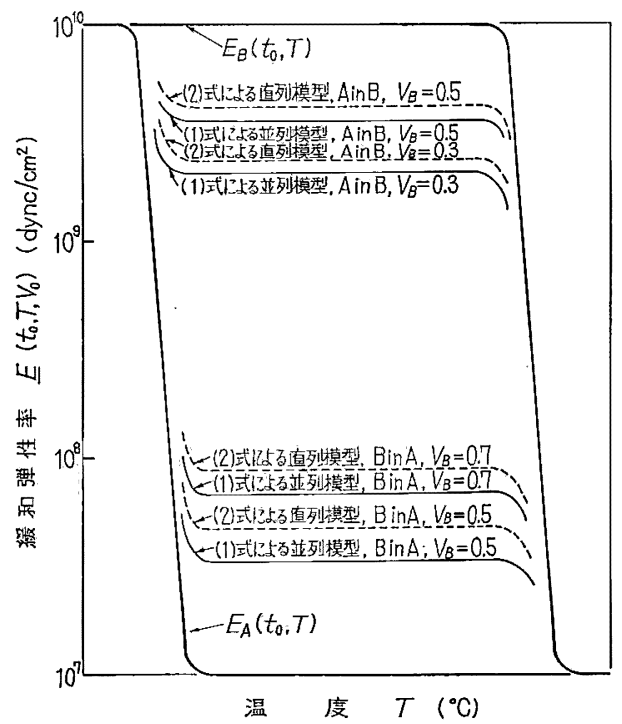

第 3 図 単純な機械的混合系の䌊和弾性率 の温度依存性

第 3 図は $E_{A}\left(t_{0}, T\right)$ 特よび $E_{B}\left(t_{0}, T\right)$ が図炕示される ように既知の場合， $E\left(t_{0}, T, V_{0}\right)$ の変化を $V_{B}=0.3,0.5$ 抢よび 0.7 の場合について，第 (1) 呿よび (2) 式によ。 て試算したものである。この結果も第 2 図の場合と同 様，傾向に捣いて著しい類似が認められ，要するに混合 系の海になっている相の性質が混合系の挙動を支配する ことを示す。

たとえば A in B の場合は B の分率が 0.3 となっ ても温度の中間領域に見られる弾性率の平衡值は $2 \times$ $10^{9} \mathrm{dyne} / \mathrm{cm}^{2}$ より低くなることはなく，また B in A の場合は B の分率が 0.7 となっても平衡值は $9 \times$ $10^{7}$ dyne $/ \mathrm{cm}^{2}$ を越すことはない。

第 2, 3 図の結果にもみられるよ5に, 同一試料の力学 挙動が第 (1) 特よび (2) 式で与兄られる等価模型の選択 により若干相違することは, 模型の非現実性, 特に上述 したように異相の界面に和けるひずみあるいは応力の分 布を極端に単純化した誤差によるるのと考兄られる。こ の誤差は混合系の挙動が主として海相の性質によって支 配されるという結諭をゆるがすほぼ大きいるのではない が，たとえば分散粒子の径が絶対值に怙いて著しく小さ くなり，体耫分率のみで挙動を記述しょうとする本現象 論には直接現われてこない比表面積が著しく大きくなっ てくるような場合，あるいは試料に加えられるひずみの 絶対值が大きくなって，本現象論で取り扱っているょう な微小ひずみ下の線型粘弾性で取り扱えなくなるょうな
場合なぞには上述の誤差は無視しえなくなろう。

\section{3. 一般化力学模型による混合状態の表現}

第1図 (b), (c) に示された力学模型は, それぞれ浮遊 球状相の大きさ平均的に一定に採り，それらの容皘分 率を考慮した一体模型より提出されたものである。換言 すれば，力線が単独相のみを通過しうる割合と両相にわ たって通過する割合を両相の分率によって表現したるの で，第 1 図 (b) は各要素について応力の加成性を，第 1 図 (c) は各要素についてのひずみの加成性を仮定したも のである。

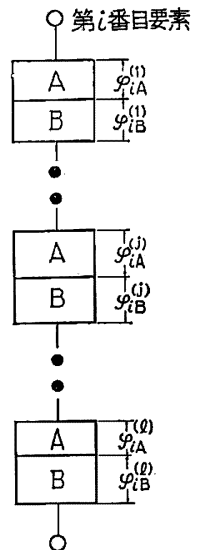

(b)

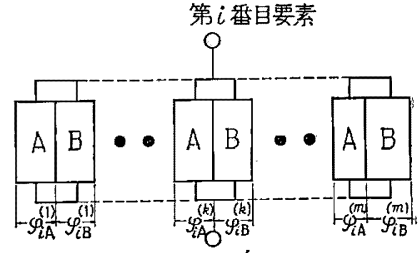

$E_{i}^{\prime}$

(c)
第 4 図

しかしながら皦密には力線が両相にわたって通過する 場合, その通過行路に和ける両相の分率はいろいると相 違するはずである。今任意の第 $i$ 番目要素に扩ける $\mathrm{A}$, B 両相の配列が第 4 図 (b), (c) で示されるとすれば，こ の要素の緩和弾性率 $E_{i}$ あるいは $E_{i}{ }^{\prime}$ は

第 4 図 (b) 飞対乙

$$
\begin{aligned}
E_{i}= & \left\{\frac{\varphi_{i A}{ }^{(1)}}{E_{A}}+\frac{\varphi_{i B}(1)}{E_{B}}+\cdots \cdots+\frac{\varphi_{i A}{ }^{(j)}}{E_{A}}+\frac{\varphi_{i B}{ }^{(j)}}{E_{B}}\right. \\
& \left.+\cdots \cdots+\frac{\varphi_{i A}{ }^{(l)}}{E_{A}}+\frac{\varphi_{i B}{ }^{(l)}}{E_{B}}\right\}^{-1} \\
= & \left\{\frac{\sum_{j=1}^{l} \varphi_{i A}{ }^{(j)}}{E_{A}}+\frac{\sum_{j=1}^{l} \varphi_{i B}{ }^{(j)}}{E_{B}}\right\}^{-1} \\
= & \left\{\frac{\varphi_{i A}}{E_{A}}+\frac{\varphi_{i B}}{E_{B}}\right\}^{-1}
\end{aligned}
$$

第 4 図 (c) 飞対し

$$
\begin{aligned}
E_{i}{ }^{\prime}= & \varphi_{i A}{ }^{(1)} E_{A}+\varphi_{i B}{ }^{(1)} E_{B}+\cdots \cdots+\varphi_{i A}{ }^{(k)} E_{A}+\varphi_{i B}{ }^{(k)} E_{B} \\
& +\cdots \cdots+\varphi_{i A}{ }^{\left({ }^{(m)}\right.} E_{A}+\varphi_{i B}{ }^{(m)} E_{B} \\
= & E_{A} \sum_{k=1}^{m} \varphi_{i A}{ }^{(k)}+E_{B} \sum_{k=1}^{m} \varphi_{i B}{ }^{(k)} \\
= & \varphi_{i A} E_{A}+\varphi_{i B} E_{B}
\end{aligned}
$$

ここで $\varphi_{i A}{ }^{(j)}, \varphi_{i B}{ }^{(j)}$ は第 4 図 (b) 要素中の第 $j$ 番目の $\mathrm{A}, \mathrm{B}$ 両相の体積分率, $\varphi_{i A}{ }^{(k)}, \varphi_{i B}{ }^{(k)}$ は第 4 図 (c) 要素 
中の第 $k$ 番自の $\mathrm{A}, \mathrm{B}$ 両相の体皘分率である。一般には 要素中に战けるたと壳ば $\mathrm{A}$ 相の分率 $\varphi_{A}$ は 0 から 1 の 間に変化すると考克られるので, 第 1 図 (b), (c) 飞対応 する力学模型として第 5 図 (b)，(c) に示すような一般化 模型を与えることができよう。

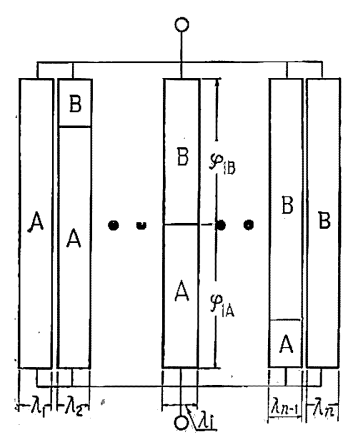

(b) 一般化並列模型

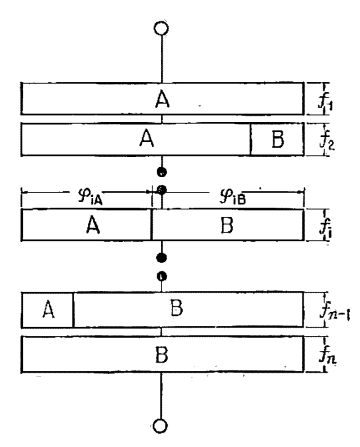

(c) 一般化直列模型
第 5 図 二つのタイプの一般化模型

第 5 図 (b) に対し系の緩和弾性率 $\underline{E}$ は

$$
\left.\begin{array}{l}
\underline{E}=\sum_{i=1}^{n} \lambda_{i} E_{i} \\
=\sum_{i=1}^{n} \lambda_{i}\left(\frac{\varphi_{i A}}{E_{A}}+\frac{\varphi_{i B}}{E_{B}}\right)^{-1} \\
\sum_{i=1}^{n} \lambda_{i}=1, \quad \varphi_{i A}+\varphi_{i B}=1 \\
\sum_{i=1}^{n} \lambda_{i} \varphi_{i A}=V_{A}, \quad \sum_{i=1}^{n} \lambda_{i} \varphi_{i B}=V_{B}
\end{array}\right\} .
$$

第 5 図 (c) に対し系の緩和弾性率 $\underline{E}$ は

$$
\begin{aligned}
& \frac{1}{\underline{E}}=\sum_{i=1}^{n} \frac{f_{i}}{E_{i}^{\prime}} \\
& =\sum_{i=1}^{n} \frac{f_{i}}{\varphi_{i A} E_{A}+\varphi_{i B} E_{B}} \\
& \sum_{i=1}^{n} f_{i}=1, \quad \varphi_{i A}+\varphi_{i B}=1 \\
& \sum_{i=1}^{n} f_{i} \varphi_{i A}=V_{A}, \quad \sum_{i=1}^{n} f_{i} \varphi_{i B}=V_{B}
\end{aligned}
$$

今年あるいは $f$ を $\varphi$ の関数と考学

$$
\begin{gathered}
\lambda(\varphi) d \varphi=\sum_{\varphi<\varphi_{i}<\varphi+d \varphi} \lambda_{i} \\
f(\varphi) d \varphi=\sum_{\varphi<\varphi_{i}<\varphi+d \varphi} f_{i}
\end{gathered}
$$

を定義し， $n \rightarrow \infty$ にとると第 (5) 特よび (6) 式は積分表 示としてそれぞれ次の第 (9)-(10) 特よび (11)-(12) 式で 与兄られる。

$$
\begin{aligned}
& \underline{E}(t, T)=\int_{0}^{1} E\left(t, T, \varphi_{A}\right) \lambda\left(\varphi_{A}\right) d \varphi_{A} \\
& \int_{0}^{1} \lambda\left(\varphi_{A}\right) d \varphi_{A}=1 \\
& \int_{0}^{1} \lambda\left(\varphi_{A}\right) \varphi_{A} d \varphi_{A}=V_{A}
\end{aligned}
$$

ここで

$$
\begin{aligned}
& E\left(t, T, \varphi_{A}\right)=\left\{\frac{\varphi_{A}}{E_{A}(t, T)}+\frac{\left(1-\varphi_{A}\right)}{E_{B}(t, T)}\right\}^{-1} \\
& \frac{1}{\underline{E}(t, T)}=\int_{0}^{1} \frac{f\left(\varphi_{A}\right)}{\underline{E}^{\prime}\left(t, T, \varphi_{A}\right) d \varphi_{A}} \\
& \int_{0}^{1} f\left(\varphi_{A}\right) d \varphi_{A}=1 \\
& \int_{0}^{1} f\left(\varphi_{A}\right) \varphi_{A} d \varphi_{A}=V_{A} \\
& E^{\prime}\left(t, T, \varphi_{A}\right)=\varphi_{A} E_{A}(t, T)+\left(1-\varphi_{A}\right) E_{B}(t, T)
\end{aligned}
$$

第 (9) あるいは (11) 式持いて左辺 $E(t, T)$ は混合系の 緩和弾性率であり，実験的に求めることができる。また 右辺 $E, E^{\prime}$ は第 (10) 执よび (12) 式によって各相の $E_{A}$, $E_{B}$ が既知である限り算出が可能である。したがって $\lambda(\varphi)$ 岁るいは $f(\varphi)$ は原理的には (9) 岁るいは (11) 第 (1) 式の積分方程式を付帯条件のるとで解くことによって決 定することができる。

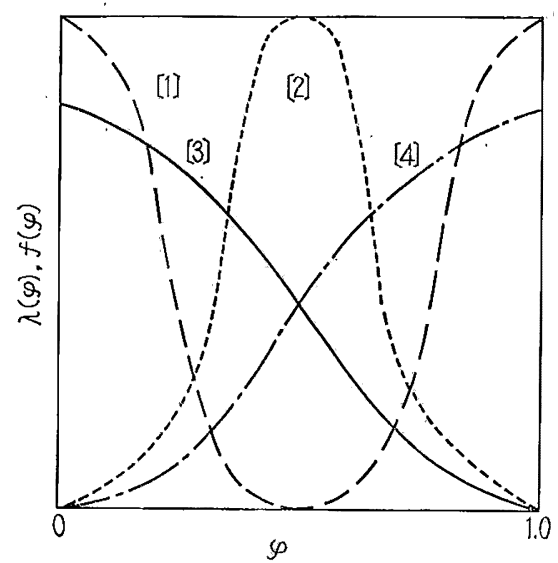

第 6 図 分布関数 $\lambda(\varphi)$ 女るいは $f(\varphi)$ に対する 4 種類の特徽的な分布型

$\lambda(\varphi)$ あるい性 $f(\varphi)$ の意味はすで符 5 図 (b), (c) か らわかるように A, B 両相の混合状態を表現する一種の 分布関数であり, その関数形は第 6 図模式的に示され るように，少なくとも4 種の代表形が想定できる。

$\lambda\left(\varphi_{A}\right)$ に対して:
（I） 海-海混合
（II）島-島混合
(III) A in B 混合
(IV). $B$ in $A$ 混合

$f\left(\varphi_{A}\right)$ に対して:
（I）島-島混合
（II） 海-海混合
(III) $A$ in $B$ 混合
(IV) $\mathrm{B}$ in $\mathrm{A}$ 混合

ここで海-海混合とは両相が力線に対し独立に貫通網状 
組織をもち,力学的江両相単純並列系の性筫を強く示す。 また島一島混合とは両相が独立, 力線火対し直交板状組 織をるち, 力学的に単純直列系の性質を強く示す。

\section{4. 混合状態を表現する分布関数 $\lambda(\varphi)$ あるいは $f(\varphi)$ の決定}

$\lambda(\varphi)$ あるいは $f(\varphi)$ の決定は第 (9) あるいは (11) 式に よって与えられる積分方程式を解くことにほかならない が，一般的には $\underline{E}(t, T)$ が解析関数の形で与兄られると は限らないのでここの解法は数值積分によらざるをえな W。

この数值皘分による解法を第 (9) 式に対し示してお く。そのため $\varphi_{A}(0 \sim 1)$ を $n$ 個の小区間 $\Delta \varphi_{A i}$ に分割 し， $\varphi_{A i}$ をその分割中の任意の值とし,さらに $(n-2)$ 個 の任意温度 $T_{1}, \ldots \ldots ., T_{n-2}$ に捈郆る $E\left(t_{0}, T\right), E\left(t_{0}, T\right.$, $\left.\varphi_{A i}\right)$ を採ると $\lambda\left(\varphi_{A i}\right)$ は次式によって与兄られる。

$$
\begin{aligned}
& {\left[\begin{array}{l}
1 \\
V_{A} \\
E\left(T_{1}\right) \\
\underline{E}\left(T_{2}\right) \\
\quad \vdots \\
\underline{E}\left(T_{n-2}\right)
\end{array}\right]=\left[\begin{array}{lll}
1 & 1 & \cdots 1 \\
\varphi_{A 1} & \varphi_{A 2} & \cdots \varphi_{A n} \\
E\left(\varphi_{A 1}, T_{1}\right) & E\left(\varphi_{A 2}, T_{1}\right) & \cdots E\left(\varphi_{A n}, T_{1}\right) \\
E\left(\varphi_{A 1}, T_{2}\right) & E\left(\varphi_{A 2}, T_{2}\right) & \cdots E\left(\varphi_{A n}, T_{2}\right) \\
\vdots & \vdots & \vdots \\
E\left(\varphi_{A 1}, T_{n-2}\right) & E\left(\varphi_{A 2}, T_{n-2}\right) \cdots E\left(\varphi_{A n}, T_{n-2}\right)
\end{array}\right]} \\
& \lambda_{i}=\lambda\left(\varphi_{A i}\right) \Delta \varphi_{A i}
\end{aligned}
$$

ここで第 (13) 式は $\lambda_{i}$ を末知数とする $n$ 元一次連立代

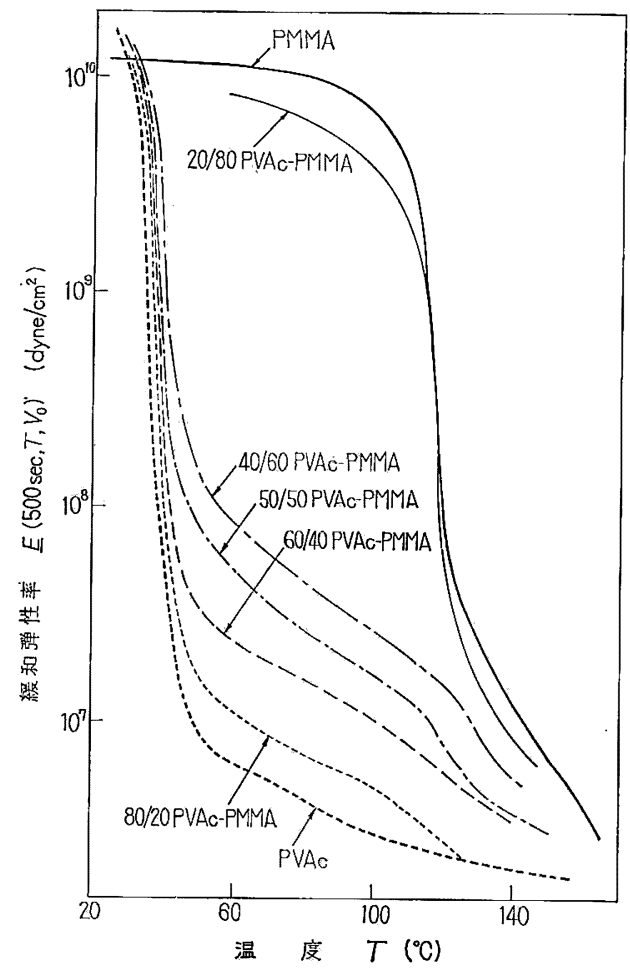

第7図 PMMA, PVAc および種々の混合分率 の PMMA-PVAc-混合系の 500 秒緩和弾性 率の温度依存性 数方程式であり，その解法は容易で岕っても，nの増大 とともに著しく手数を要し， $n$ を 20 程度に採っても， もはや電子計算機にまかすべき仕事となろう。

\section{5. 二三の実験例と解析結果}

5-1. ポリメタクリル酸メチル (PMMA)-ポリ酢酸ビ ニル (PVAc) 混合系によるモデル実験と PMMA 橋か け微粒子-PVAc 混合系の挙動

PVAc $\left(\bar{M}_{\eta}: 2.4 \times 10^{6}\right)$ そ PMMA $\left(\bar{M}_{\eta}: 3.5 \times 10^{5}\right)$ を アセトンを共通溶剂として混合溶液より製膜した試料の 500 秒緩和弾性率の温度依存性 $\underline{E}\left(500, T, V_{0}\right)$ を第 7 図 に示す。

PMMA, PVAc のいずれるそれぞれ約 $120,40^{\circ} \mathrm{C}$ 近 辺炕いて弾性率の急激な低下を示し，無定形顉状高分 子物質としての典型的な，いわゆるガラスーゴム転移を 示す。一方, 両者の混合物は 20/80 PVAc-PMMA 飞 $\times\left[\begin{array}{c}\lambda_{1} \\ \lambda_{2} \\ \lambda_{3} \\ \lambda_{4} \\ \vdots \\ \lambda_{n}\end{array}\right]$ ついては低温側のデータK欠くので明確では ないが，他の混合物についてはいずれる上述 の転移を相当温度領域に水いて示し，両成分 の混合様式が単純な機械混合であることを暗 示する。

ここで最も特徵的なことは混合物の挙動の 混合分率依存性であって, PMMA の分率が $60 \%$ に達 するまでの一群の混合物の挙動は PVAc 単独物にきえ

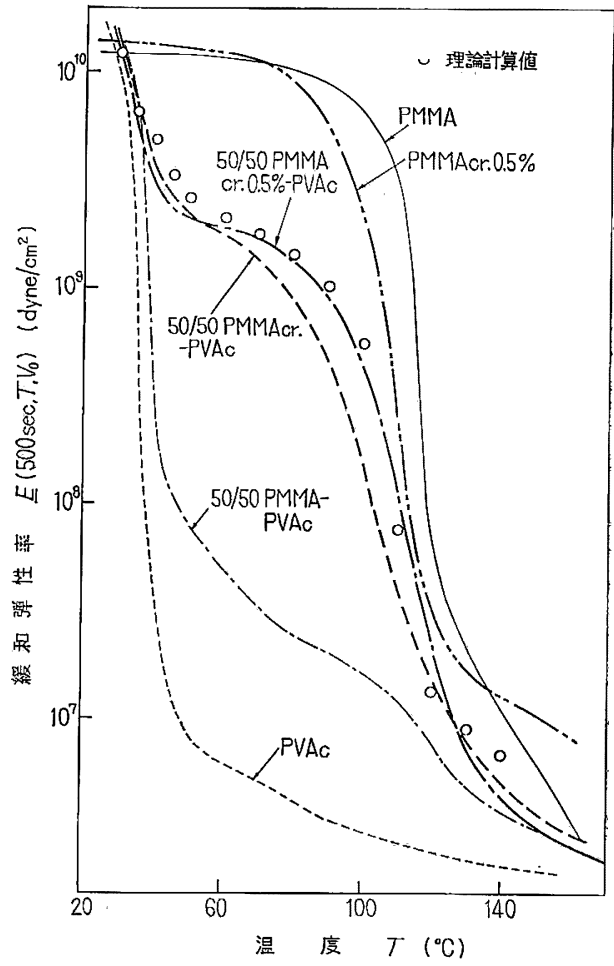

第 8 図 50/50 橋かけ PMMA 微粒子-PVAc 混合系掠よび橋かけ PMMA の 500 秒緩和 弾性率の温度依存性 
めて近く, $80 \%$ に達して初めて飛躍的に PMMA 単独 物に近づくことである。

$\operatorname{PVAc}\left(\bar{M}_{\eta}: 2.4 \times 10^{8}\right)$ のアセトン溶液へ，アリルメタ クリレートーメチルメタクリレートの 0.5/99.5 ※たは $3 /$ 97 の割合の乳合共重合によって得られた粒径約 $100 \mathrm{~m} \mu$ の PMMA 橋か子行微粒子. (PMMA Cr. 0.5\%, PMMA Cr. 3\%) をPVAc に対し 50/50 の分率で混入し，十分 膨潤均一拡散した溶液より製膜した試料の 500 秒緩和 弾性率の温度依存性を第 8 図に示す。また図中には比較 のため上述の $0.5 \%$ 橋かけ微 PMMA 粒子のみよりアセ トン膨潤により製膜された皮膜の結果, および純 PVAc, PMMA および 50/50 PMMA-PVAc の結果も示して ある。

PMMA Cr. 0.5\% の結果は純 PMMA に比較して転 位領域が若干低温側にずれて物り，橋かけ物としての一 般的傾向に反するが，純 PMMA に見られるゴム領域に 打ける流動性は著しく減少されている。50/50 PMMA Cr.-PVAc 混合物の挙動はいずれる両成分の転移を相等 温度領域に拉いて示し，再び両成分の混合が単なる機械 混合であることを暗示するが，緩和弾性率の温度依存性 は同じ混合分率の 50/50 PMMA-PVAc に比較して著し く高弾性率侧にずれており，混合様式の相違を暗示する。 第 9 図は第 7 図蛙よび第 8 図に示され机混合系の緩和 弾性率の混合分率依存性をチェックするため $80^{\circ} \mathrm{C}$ に拉 ける值を分率に対しプロットした結果である。図中黒点 は PMMA-PVAc 混合系の測定点を示す。細実線は PMMA，PVAc 単独物の緩和弾性率の值を用い，第 (1) 式によって PMMA の分率 70\% に打いて PIMMA in PVAc より PVAc in PMMA への相転換が生ずると仮 定した計算值である。両者の間に若干の不一致はあって も, 分率 70\% 近辺の相転換に上る混合物の緩和弾性率 の飛躍的な上昇はよく説明されて拈り，この混合系が PVAc の海に PMMA の島が浮んだ混合様式から出発 して, PMMA の分率の增大とと为に六方最密充てんに 括いて PMMA の海に PVAc の島が浮ぶ混合様式に転 ずることを強く暗示する。事実 PMMA の分率 70\% 以 下の皮膜はいずれるPVAc のみの溶剂である熱エタ，

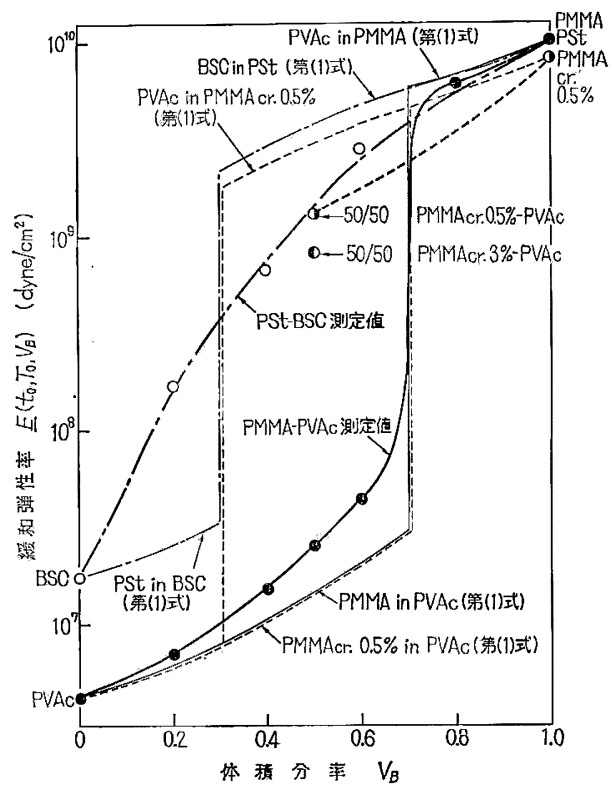

第 9 図 PMMA-PVAc 混合系, PMMA Cr.PVAc 混合系および PSt-SBR 混合系の $80^{\circ} \mathrm{C}$ に打ける緩和弾性率の混合分率依存性 と第 (1) 式による島一海混合を仮定した計算 值との比較

ールで抽出を行ならと形態をとどめないが, 20/80 PVAc -PMMA は十分に形態をとどめるのである。

これに反し PMMA 橋か子微粒子-PVAc 混合系は図 中半黒点で示されるが, その挙動はたとえば PMMA Cr. 0.5\%-PVAc について島-海混合を仮定して第 (1) 式によ って算出された細点線の結果からは大きく離反し, 混合 状態が 簡単な島海混合ではなく, 海-海混合すなわり両 相の連続網状組織よりなることを暗示する。事実 PVAc のみの溶剤である熱エタノールで皮膜の PVAc の抽出 を行なっても十分に皮膜の形態を保って扣り，少なくと も PMMA 相が連続網状組織を形成していることを示 している。

第 8 図に示されるような PVAc, PMMA Cr. 0.5\% 打 よび 50/50 PMMA Cr. 0.5\%-PVAc の 500 秒緩和弾性 率の温度依存性加 50/50 PMMA Cr. 0.5\%-PVAc の

第 1 表 50/50 PMMA Cr. 0.5\%-PVAc 混合系の $V_{A}=0.5$ の場合 $n=11$ として数值計算により得られた $f_{A i}$ 抒よび $\varphi_{A i}$ の值

\begin{tabular}{c|c||c|c}
\hline \hline$\varphi_{A i}$ & $f_{i}$ & $\varphi_{A i}$ & $f_{i}$ \\
\hline$\varphi_{1}: 0.05$ & $1.9 \times 10^{-8}$ & $\varphi_{7}: 0.6$ & $1.8 \times 10^{-1}$ \\
$\varphi_{2}: 0.1$ & $1.7 \times 10^{-2}$ & $\varphi_{8}: 0.7$ & $1.2 \times 10^{-1}$ \\
$\varphi_{3}: 0.2$ & $5.3 \times 10^{-2}$ & $\varphi_{9}: 0.8$ & $5.5 \times 10^{-2}$ \\
$\varphi_{4}: 0.3$ & $1.2 \times 10^{-1}$ & $\varphi_{10}: 0.9$ & $1.8 \times 10^{-2}$ \\
$\varphi_{5}: 0.4$ & $1.9 \times 10^{-1}$ & $\varphi_{11}: 0.95$ & $1.5 \times 10^{-3}$ \\
$\varphi_{6}: 0.5$ & $2.3 \times 10^{-1}$ & & \\
\hline
\end{tabular}

$V_{A}:$ PVAc 分率, $f_{i}=f\left(\varphi_{A i}\right) \Delta \varphi_{A i}$

Vol. 12, No. 139 
分布関数 $f(\varphi)$ を，(10） 预よび (11) 式を使用し， $n=11$ と置いて数值計算によって求めてみた。得られた結果は 第 1 表に示されるが，分布関数 $f(\varphi)$ は $\varphi=0.5$ の近辺 でガウス分布の形を示し, 筑 6 図の (2) の型電するる のの上らである。したがってこの系の混合状態は海一海 混合であると考党られ，PMMA-PVAc 混合系の島一海 混合とは全く異種のものであることを暗示している。第 8 図にプロットされた白丸点は第 1 表の值を(13) 式に 代入して計算して得たものであるが，太い鎖線の実験值 とよく一致している。

5-2. ポリスチレン (PSt) と 30/70 ブタジエンースチ

\section{レン共重合ゴム (SBR) 混合系の挙動}

第 10 図に Tobolsky9) によって与兄られたポリスチ レン-30/70 ブタジェンースチレン共重合ゴム混合系の 10 秒緩和弾性率の温度依存性を示す。混合分率の変化化 5 弾性率の变化が前述の PMMA-PVAc 混合系に比較 して比較的緩慢であることが特徽である。また両成分の ガラス転移領域は混合物に物いてる SBR の転移はかな り高温側にずれている可能性は嵓っても，一応明確に分 離存在して括り，混合系が機械的混合の性格を示す。

この場合にもたとえば一定温度 $80^{\circ} \mathrm{C}$ に和ける緩和弾 性率の混合分率依存性をチェックすると，第 9 図白丸点 のようになりこれは単純な島一海混合を仮定し，ポリス チレン $30 \%$ の分率で相転換が起こると仮定して第 1 式 によって試算した結果，すなわち図中細鎖線とは全く相 違し，混合状態の特異性を示す。

再びこの混合系の各成分の緩和弾性率の温度依存性か ら，混合系の分布関数 $\lambda\left(\varphi_{A i}\right)$ を(10) 拉よび (11) 式を 用いて数值計算によって求めてみたが，この計算值は高 温部と低温部に括壮る混合系の緩和弹性率の変化が比較 的緩慢であるために，特にポリスチレンの分率の高いと ころで実験值との不一致が見られた。そこでさらに 30 $\sim 100^{\circ} \mathrm{C}$ の温度範囲の緩和弾性率の温度依存性から, $n$ $=6$ として数值積分法によってこの計算を行なった。

4 種類の混合系について計算された結果が第 2 表に示 される。この表から $\lambda\left(\varphi_{A i}\right)$ は $\varphi_{A i}$ の両端で極大を採る

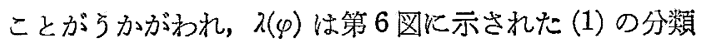
すなわち海-海混合の性格をるつことを暗示する。

第 2 表の值を用いて逆計算された結果を第 10 図点線 で示す。絬果は比較的実験結果をよく再現するが，一致 の程度は前述の場合ほど良好ではなく, 特に高ポリスチ レン分率の高, 低温側に系統的なずれが認められる。こ の原因は数值積分に採用された $n$ の值が小さすぎるか， あるいは本混合系がこの現象理諭で取り扱われたような 単なる機械混合系ではなく，若干分子オーダに混合した 両成分間の相互作用性を考慮しなければならない系であ るためでめろう。

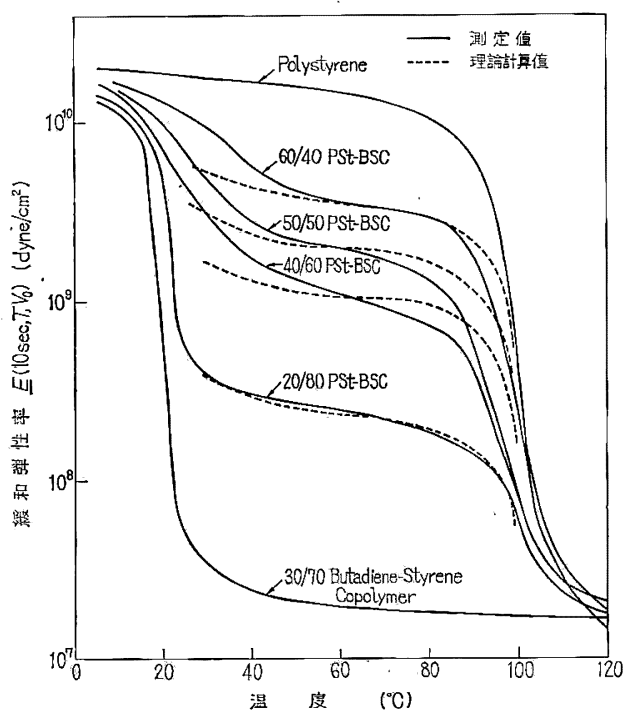

第 10 図 種々の混合分率の PSt-SBR 混合系の 10 秒緩和弾性率の温度依存性

(Tobolsky, 1960)

事実第 10 図にも見られるよ5に混合系の高, 低温部 に抢ける緩和弾性率の温度依存性は，たとえば単なる機 械混合を仮定して，第 3 図に示したような傾向よりはる かに広い温度範囲に変化し，これが計算值との不一致を まねいている。この原因はやはり両成分間の相互作用性 による兩相のガラス転移温度のシフトを想定すべきで,

第 2 表 ポリスチレン-30/70 ブタジェンースチレン共重合物の $V_{A}=0.8,0.6,0.5$, 扰よひ 0.4 の 4 種の混合系に対し $n=6$ として数值計算により得られた $\lambda_{i}$ 特よび $\varphi_{A i}$ の值

\begin{tabular}{c|c|c|c|c}
\hline \multirow{2}{*}{$\varphi_{A i}$} & \multicolumn{3}{|c}{$\lambda_{i}$} \\
\cline { 2 - 5 } & $V_{A}=0.8$ & $V_{A}=0.6$ & $V_{A}=0.5$ & $V_{A}=0.4$ \\
\hline$\varphi_{1}: 0.001$ & $2.3 \times 10^{-2}$ & $1.0 \times 10^{-1}$ & $2.1 \times 10^{-1}$ & $4.2 \times 10^{-1}$ \\
$\varphi_{2}: 0.01$ & - & $1.3 \times 10^{-1}$ & $1.8 \times 10^{-1}$ & $1.1 \times 10^{-1}$ \\
$\varphi_{3}: 0.1$ & $1.5 \times 10^{-1}$ & $1.2 \times 10^{-1}$ & $6.0 \times 10^{-2}$ & $5.0 \times 10^{-2}$ \\
$\varphi_{4}: 0.3$ & $5.0 \times 10^{-2}$ & $5.0 \times 10^{-2}$ & $4.0 \times 10^{-2}$ & $3.0 \times 10^{-2}$ \\
$\varphi_{5}: 0.6$ & $2.0 \times 10^{-2}$ & $4.2 \times 10^{-2}$ & $7.0 \times 10^{-2}$ & $1.0 \times 10^{-2}$ \\
$\varphi_{6}: 1.0$ & $7.6 \times 10^{-1}$ & $5.3 \times 10^{-1}$ & $4.4 \times 10^{-1}$ & $3.8 \times 10^{-1}$ \\
\hline
\end{tabular}

$V_{A}$ ：共重合体分率， $\lambda_{i}=\lambda\left(\varphi_{A i}\right) \Delta \varphi_{A i}$ 
たとえば Tobolsky はこの系を “Polyblend”と呼え で，単なる機械混合とは区別しているのである

\section{6. むすび}

相溶性のある系を除き，一般に 2 成分ポリマー混合系 娃半微視的に不均一ないわゆる 2 相機械的混合系である と想定して, 混合状態と力学的性質を関係づける一般化 モデルの誘導を試みた。

ここでは比較的一般的な力学モデルに基いて，A，B 2 成分機械的混合系の混合状態は, A 島 $-\mathrm{B}$ 海, B 島-A 海, $\mathrm{A}$ 海-B 海, $\mathrm{A}$ 島-B 島の 4 種類の様式に分類され, 混合系の力学的性質はたと文混合率が同一であっても2 相の 混合様式によって著しく左右されることを指摘し た。

もらろんこの現象理論では二つのポリマー成分間の相 互作用は無視され，2 相界面に打けるひずみあるいは応 力の分布を全く単純化している。そのために浮遊粒子の 大きさが絶対值に拈いて著しく小さくなり，比表面積が 著しく大きくなってくるような場合には，当然この誤差 は大きくなってくると予想される。

しかしながら，このような誤差は予想されるとしても， 混合系の機㭜的性質はその混合様式に大きく支配される ということ，換言すれば，その系の海相の性質に大きく 左右されるということに変わりはない。したがってこれ ら混合系の研究にめたっては，2 相がいかなる理由によ
って上述の混合㥞式に分かれなければならないかという 2 相相互間の相選択性に関する本質的原因を探究するこ とが最も大切であろう。このためにはまず，相分離の立 場から物理化学的な研究を推進することが必要である 5 。

\section{文献}

1) R. Buchdahl, L. E. Nielsen: J. Polymer Sci., 15, 1 (1955)

2) M. Gordon, J. S. Taylor : J. Appl. Chem., 2, 495 (1952)

3) A. V. Tobolsky, E. Catsiff : J. Am. Chem. Soc., 76, 4202 (1952)

4) K. Fujino, K. Senshu, H. Kawai : J. Colloid Sci., 16, 262 (1961)

5) M. Kawamata, Y. Inoue: J. Chem. Soc., Japan (Ind. Chem. Sec.), 63, 1831 (1960)

6) M. Takayanagi, H. Harima, Y. Iwata : $J$. Soc., Material Science, Japan (formerly J. Japan Soc. for Testing Materials), 12, 389 (1963)

7) E. Jenkel, H. U. Herwig: Kolloid-Z., 148, 57 (1956)

8) J. D. Ferry: "Visco-elastic Properties of Polymers ", 270 275 (1961) John Wiely and Sons, Inc., New York

9) A. V. Tobolsky: "Properties and Structure of Polymers ", 78 83 (1960) John Wiely and Sons, Inc., New York

\section{・ュュース}

\section{ドイツの立体特異性合成ゴム}

Recklinghansen, Marlkrs の “Huls 化学会社” Leverkusen の“Bayer 会社”とは共同して, “立体 ゴム会社 $\mathrm{GmbH}$ ”を Leverkusen に創設し，支社を Marl に置いた。設立資本の $50 \%$ にめたる 5 万ドイッ マルクを双方の会社が持っている。その事業の目的は立 体特異性合成ゴム生産の基礎を作成企図することにも る。支配人には, Franz Broich (Huls 化学会社) と Hermann Holzrichter (Bayer 会社)が仕命された。 “Huls” と “Bayer” はともに, 立体特異重合の領域に おいて長年にわたり，研究，開発に力を入れてきている。

(Europa Chemie., 1963 [13] 5 (1963)

(日本科学技徳情報センター提供)

\section{キャブレータ用フォームラバーフロート}

Stanmore にある Zenith Carburettos 社では Stromberg 一定真空キャブレータに取り付将るトウインフロ ートに，従来真ら济うを使用していたが，こんど気泡性 ニトリルゴムを採用した。
Zenith 社はカドミウムメッキの真ちゅう製スタンピ ングを Expanded Rubber \& Plastic 社に送り，そこ でニトリルゴム (Onazote) のフロートを取り付ける。

Zenith 社がニトリルゴム製のフロートを採用したの は，軽量化が目的というよりも，金属製フロートの場合 の組立作業を除くのが目的である。実際重さはほとんど 変わらない。

成形工程を取る場合の利益は，正確な複製が得やすい ということである。またニトリルゴム製のフロートはガ ソリンに対する耐性がある。フォームラバーは，成形時 は一様の表面を有し，表面が破れた場合でもガソリンが 中にしみ込むことがなく，複雑な成形ができるのも有利 な点である。

ニトリルオナゾートは沸騰している然料油中でも安定 で，空気中では $120^{\circ} \mathrm{C}$ まで安定性を保つ。また，その 他の溶剤, アルコール, パラフィン,トルエン, キシン ンなどを含む燃料にもほとんど影響されないので，広く 液面計，燃料流量調節計に採用されるだろらと期待され ている。(Engineering, 196 [5072] 19 (1963)

（日本科学技衔情報センター提供） 